\author{
JURNAL EINSTEIN \\ Jurnal Hasil Penelitian Bindang Fisika \\ Available online http://jurnal.unimed.ac.id/2012/index.php/inpafi \\ e-issn: $2407-747 x$, p-issn $2338-1981$
}

\title{
UJI DAYA ABSORBANSI ETANOL PADA DAUN SIRIH HIJAU (Piper betle L.) DENGAN METODE SPEKTROFOTOMETRI UV-VIS
}

\author{
Fitrisia Krisa Bella Gultom, Jelita Nababan, Tama Melati Sinambela, Tia Harizka, dan \\ Rahmatsyah
}

Fakultas Matematika dan Ilmu Pengetahuan Alam, Universitas Negeri Medan, Indonesia

agustinsitorus49@gmail.com

Diterima April 2017; Disetujui Mei 2017; Dipublikasikan Juni 2017

\begin{abstract}
ABSTRAK
Sirih merupakan tanaman menjalar dan merambat pada batang pohon di sekelilingnya dengan daunnya yang berbentuk jantung, berujung runcing, tumbuh bersilang-seling, bertangkai, teksturnya agak kasar dan mengeluarkan bau jika diremas. Batangnya berwarna cokelat kehijauan, berbentuk bulat dan berkerut. Sirih hidup subur dengan ditanam di daerah tropis dengan ketinggian 300-1000 $\mathrm{m}$ di atas permukaan laut terutama di tanah yang banyak mengandung bahan organik dan air. Tujuan dari penelitian ini adalah untuk mengetahui daya absorbansi spectrum cahaya pada rendaman daun sirih hijau dengan pelarut etanol yang divariasikan konsentrasinya yaitu 50\%, 70\%, dan 96\%. Metode penelitian yang digunakan adalah analisis gelombang spectrum menggunakan Spektrofotometri UV-Vis. Hasil penelitian menunjukan bahwa rendaman daun sirih hijau dengan pelarut etanol $70 \%$ merupakan absorbansi terbaik dari tiga variasi larutan yang diuji. Hal ini ditunjukkan dengan gambar gelombang spectrum yang didapatkan. Sampel yang paling efektif mengabsorbat spektrum adalah pada sampel dengan konsentrasi etanol 70\%.
\end{abstract}

Kata Kunci : Daun Sirih Hijau, Pelarut Etanol, Gelombang Spektrum 


\section{PENDAHULUAN}

Indonesia merupakan salah satu Negara tropis yang terkenal dengan keanekaragaman tanamannya yang dapat digunakan sebagai obat. Bagian tanaman yang dapat digunakan sebagai obat berupa daun, batang, buah, bunga dan akar (Peoloengan et al. 2006).

Sirih merupakan salah satu jenis tumbuhan yang banyak dimanfaatkan untuk pengobatan. Tumbuhan ini merupakan family Peperaceae, tumbuh merambat dan menjalar dengan tinggi mencapai 5-15 m tergantung pertumbuhan dan tempat rambatnya. Bagian dari tumbuhan sirih (Pipper batle L.) seperti akar, biji, dan daun berpotensi untuk pengobatan, tetapi yang paling sering dimanfaatkan adalah bagian daun (Damayanti R, 2003).

Daun sirih memiliki bentuk seperti jantung, berujung runcing, tumbuh berselang seling, bertangkai, teksturnya kasar jika diraba, dan mengeluarkan bau yang sedap (aromatis). Panjang daun $6-17,5 \mathrm{~cm}$ dan lebar 3,5-10 cm.Tanaman sirih hijau (Pipper batle L.) tumbuh subur disepanjang Asia tropis hingga Afrika Timur menyebar hampir di seluruh wilayah Indonesia, Malaysia, Thailand, Sri Lanka, India hingga Madagaskar. Di Indonesia, tanaman ini dapat ditemukan di pulau Jawa, Sumatra, Kalimantan, Sulawesi, Maluku dan Papua (Putri ZF, 2010). Komponen kimia sirih adalah minyak atsiri, seskuiterpen, triterpen, terpenoid, sitosterol, neolignan, krotepoksid (Sudarsono, dkk., 1996).

Absorbsi adalah peristiwa masuknya zat cair pada zat padat atau zat cair lain. Pada absorbsi terjadi pada gejala yang memiliki fenomena ruah di keadaan endotermik sehingga tidak dipengaruhi suhu yang mengakibatkanb laju reaksi yang seragam pada konsentrasi yang sama. Absorbsi terjadi ketika partikel melewati atau memasuki suatu material yang bersifat ruah (bulky).
Selama absorbsi, molekul terlarut atau terdifusi sepenuhnya didalam absorben untuk membentuk suatu larutan. Setelah larut, molekul tidak dapat dipisahkan secara mudah dari absorben.

Absorbsi merupakan fenomena dengan substansi mempertahankan energy radiasi panjang gelombang tertentu. Kaca biru menyerap semua cahaya kecuali panjang gelombang dibagian biru dari spectrum, tetapi juga mengacu pada hilangnya sebagian energi gelombang elektromagnetik yang dihasilkan dari cahaya dan lainnya melewati medium.

Dalam kimia, absorbsi merupakan proses substansi yang menembus substansi lain seperti dalam menyerap cairan atau diserap oleh padatan.

Untuk mendeteksi daya absorpsi spectrum pada sampel hasil larutan daun sirih hijau dengan pelarut etanol maka diperlukan metode dan alat ukur yang dapat mengukur parameter gelombang spectrum yang ada pada sampel tersebut. Metode yang digunakan untuk menganalisis gelombang spectrum tersebut dengan menggunakan metode Spektrofotometri UV-Vis.

\section{METODE PENELITIAN}

Bahan yang digunakan pada penelitian ini adalah Daun sirih hijau, pelarut etanol 50\%, $70 \%$, dan $96 \%$. Sedangkan peralatan yang digunakan adalah seperangkat alat Spektrofotometer UV-Vis, neraca analitik, gelas ukur, Erlenmeyer, pipet tetes.

\section{Pembuatan Larutan Baku}

Ditimbang sebanyak 200 gr daun sirih hijau, dikeringkan, kemudian di potong kecilkecil. Dimasukkan kedalam Erlenmeyer yang berisi pelarut etanol. Dibuat tiga variasi dengan konsentrasi pelarut yang berbedabeda yaitu 50\%, 70\%, dan 96\%. Setelah itu ditutup rapat, dan dimaserasi selama 3 hari. 
Fitrisia Krisa Bella Gultom, Jelita Nababan, Tama Melati Sinambela, Tia Harizka, dan Rahmatsyah, Uji Daya Absorbansi Etanol Pada Daun Sirih Hijau (Piper betle L.) Dengan Metode Spektrofotometri UV-VIS

\section{Penentuan Kadar Sampel}

Dibaca serapan sinar (absorbansi) dengan spektrofotometer untuk melihat panjang gelombang dengan blanko serapan etanol.

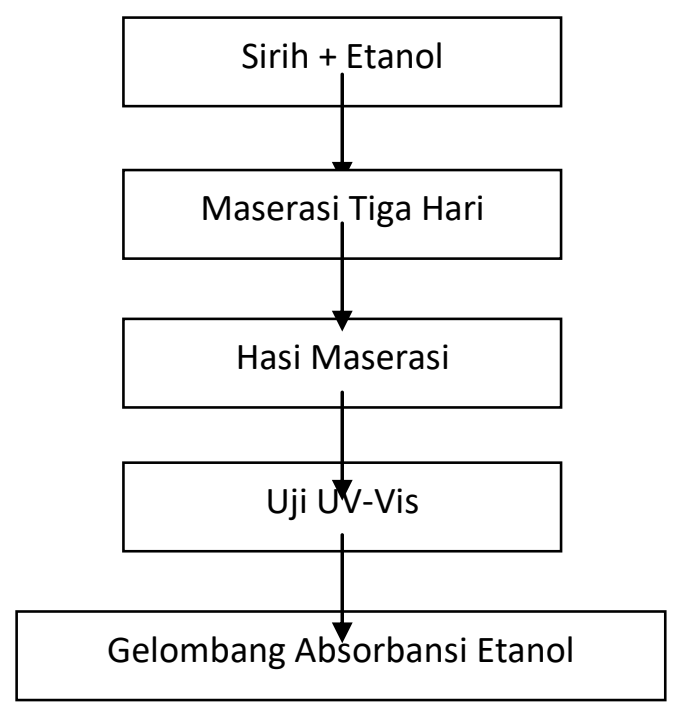

Gambar 1. Diagram Metode Penelitian

Sampel maserasi daun sirih dengan pelarut etanol 50\%

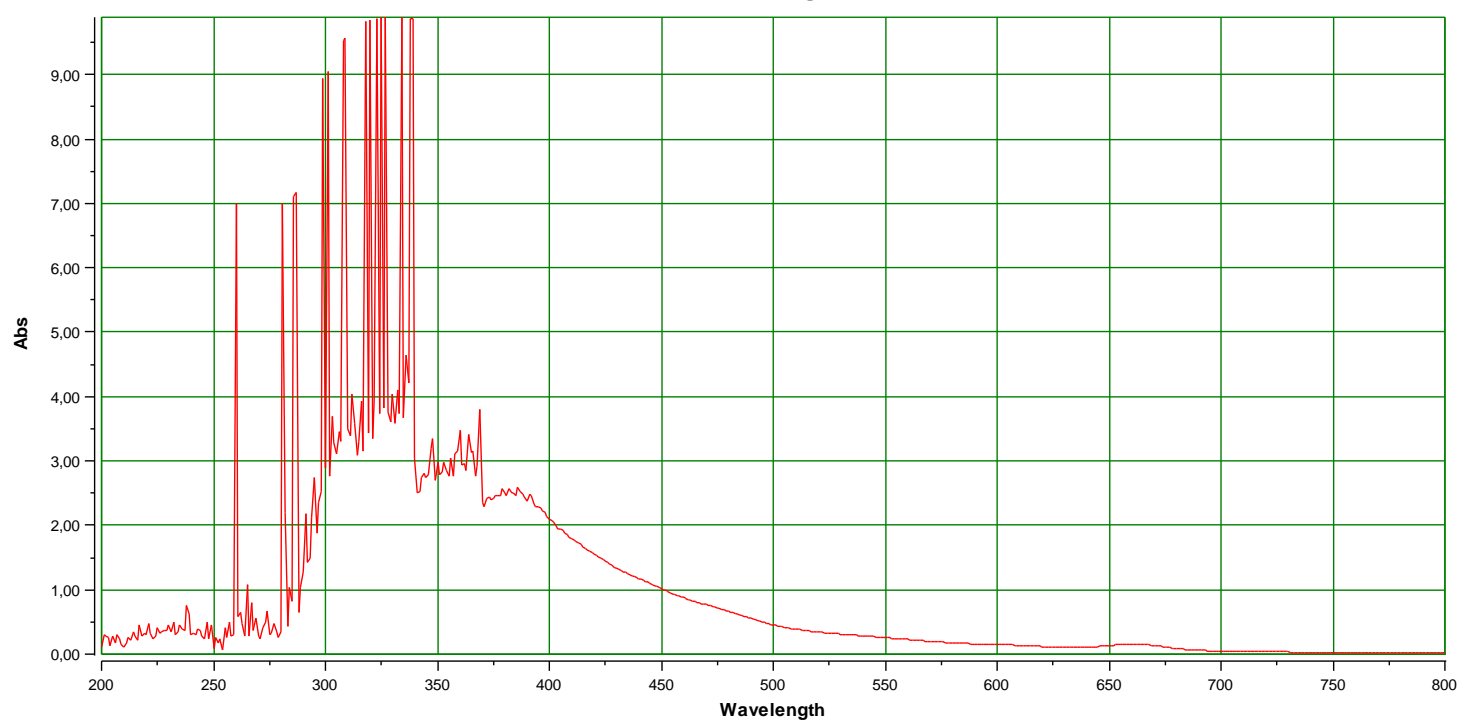

Gambar 2. Bentuk gelombang spectrum pelarut etanol 50\%

Hasil menunjukkan bahwa pada ditunjukkan oleh Gambar 2, ketika spectrum sampel ini tidak terjadi absorban untuk dari 400nm hingga seterusnya baru lah spectrum ultraviolet nya. Namun untuk terlihat peristiwa absorbansi pada sampel cahaya tampak, pada sampel ini terlihat dengan pelarut etanol $50 \%$ tersebut. bahwa terjadi absorbansi. Seperti yang

\section{HASIL DAN PEMBAHASAN}

Pada pengujian kualtitatif absorbansi menggunakan metode spektrofotometri UVVis, maka dilakukan pembuatan kurva standar larutan hasil maserasi daun sirih dengan pelarut etanol. Larutan dibuat dengan konsentrasi 50\%, 70\%, dan 96\%. 
Sampel maserasi daun sirih dengan pelarut etanol 70\%

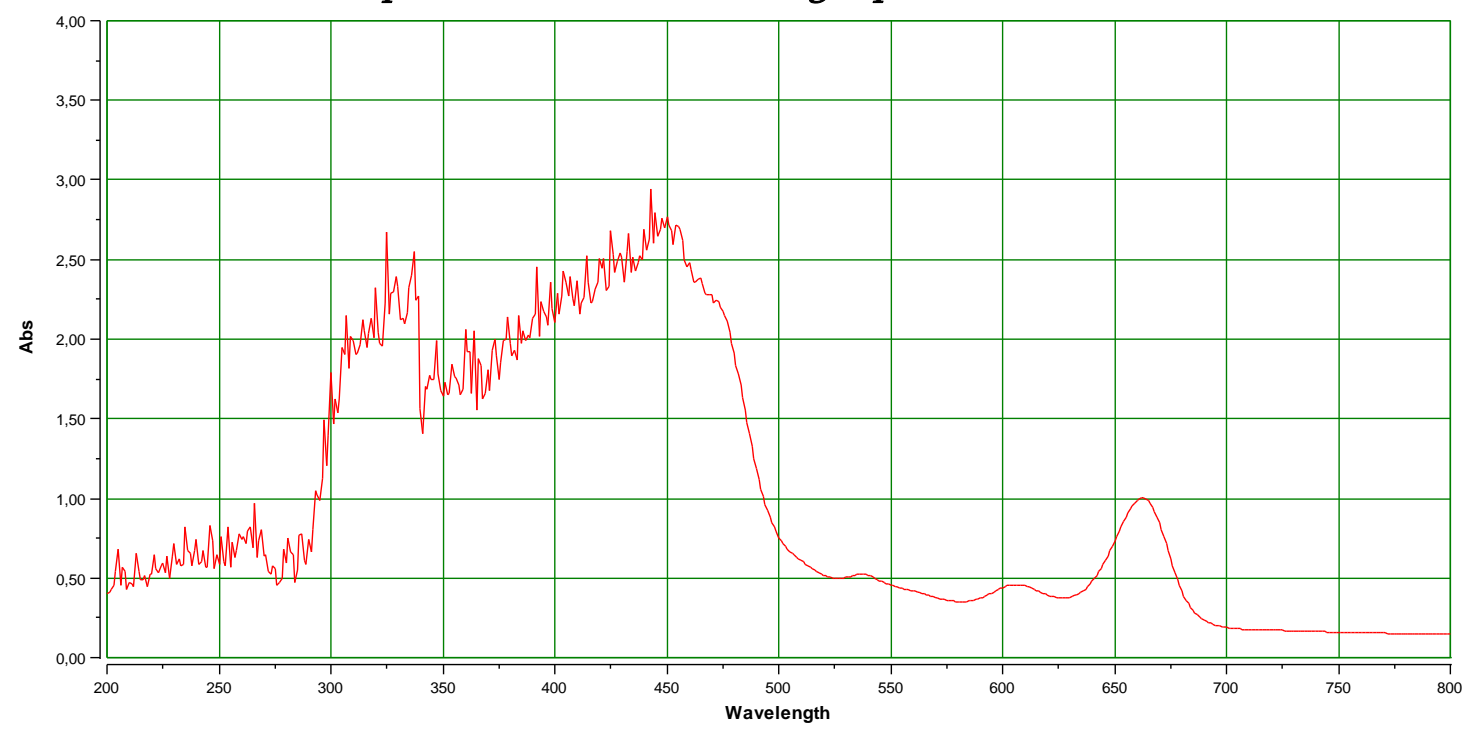

Gambar 3. Bentuk gelombang spectrum pelarut etanol 70\%

Ketika pengujian sampel dengan ultraviolet hanya sedikit saja terjadi pelarut etanol 70\%, ditunjukkan oleh gambar absorbansi, sedangkan pada spectrum cahaya bahwa terjadi absorbansi pada spectrum tampak terlihat jelas bahwa terjadi absorbansi Ultraviolet maupun Visible. Pada spectrum yang lebih besar.

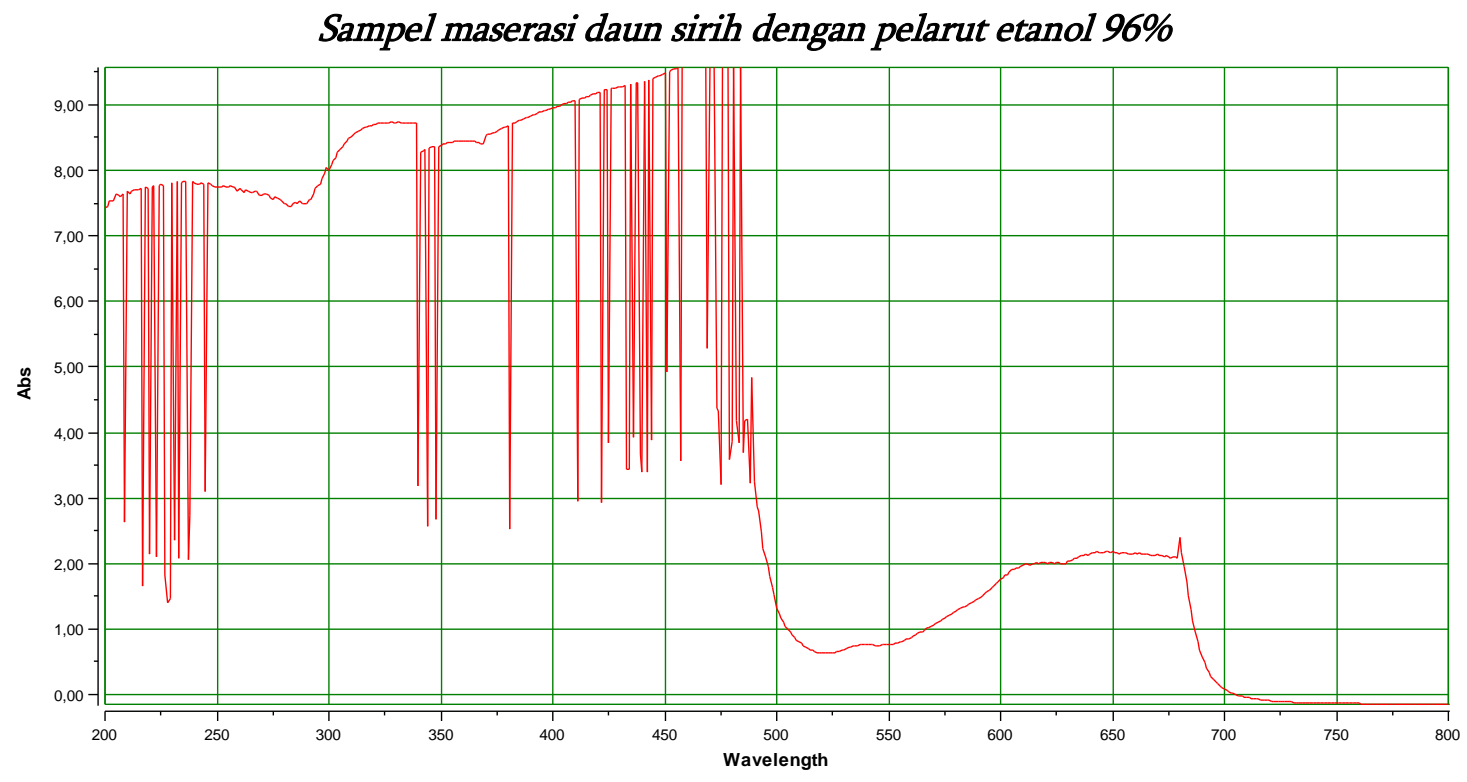

Gambar 4. Bentuk gelombang spectrum pelarut etanol 96\% 
Pengujian sampel dengan pelarut etanol sebaik pelarut tersebut. Pada pelarut $96 \%$ juga $96 \%$, terlihat bahwa terjadi absorbansi. Hamper terjadi absorbansi pada spectrum UV dan Vis. sama dengan pelarut etanol $70 \%$ namun tidak

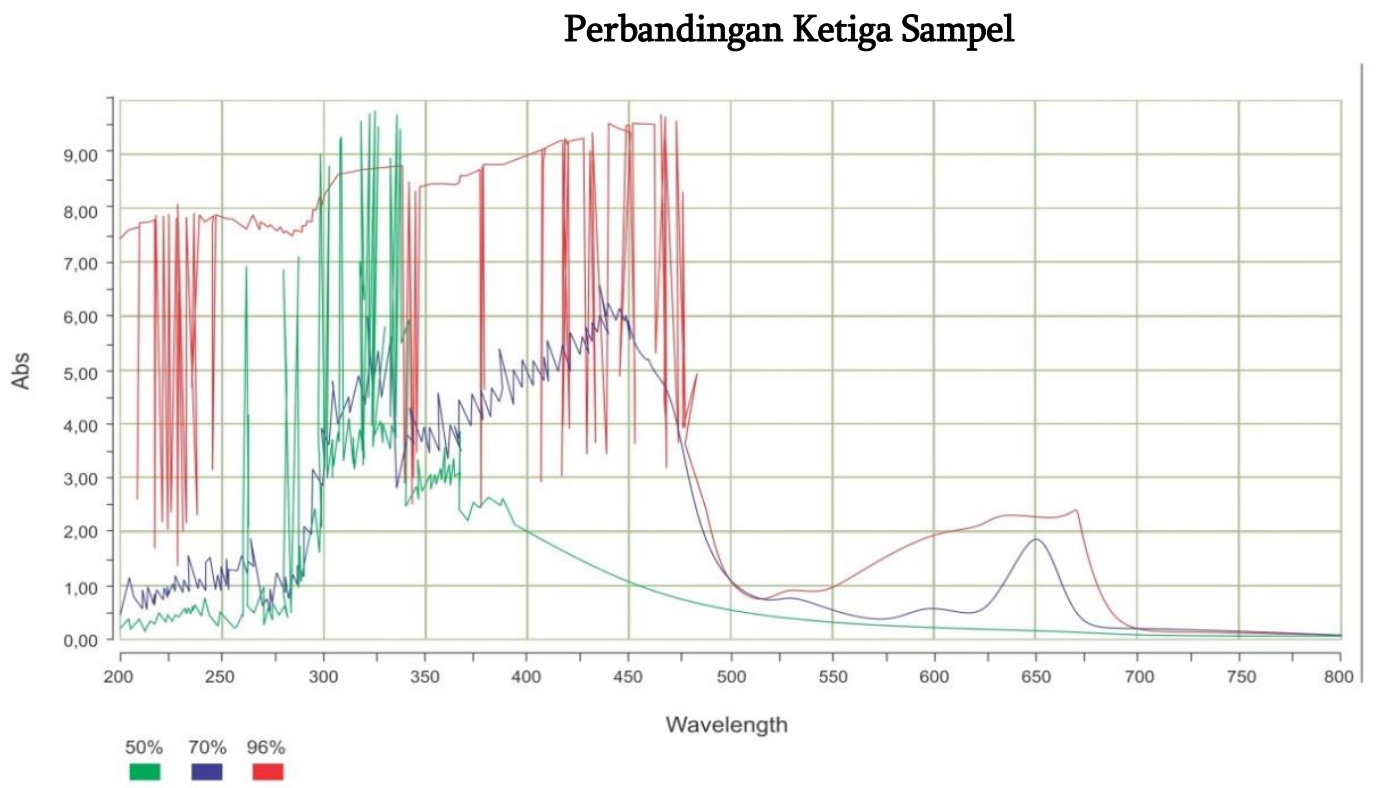

Gambar 5. Perbandingan Gelombang Absorbansi Ketiga Sampel

Berdasarkan perbandingan gelombang spectrum dari tiga variasi pelarut etanol $50 \%, 70 \%$, dan $96 \%$ terlihat bahwa sampel dengan pelarut etanol $70 \%$ memiliki daya absorbansi paling baik dari dua pelarut etanol lainnya. Hal ini dikarenakan pada panjang gelombang maksimal, kepekaannya juga maksimal karena pada panjang gelombang tersebut adalah paling besar. Selain itu disekitar panjang gelombang maksimal, terbentuk kurva absorbansi yang datar sehingga hukum Lambert-Beer dapat terpenuhi.

\section{KESIMPULAN}

Dari hasi penelitian uji absorbansi menggunakan metode Spektofotometri Uv-Vis yang telah dilakukan, didapatkan hasil bahwa sampel dengan pelarut 3tanol $70 \%$ merupakan sampel yang memiliki daya absorbansi paling baik diantara sampel lainnya. Hal ini dikarenakan pada sampel $70 \%$ terlihat adanya absorbansi pada spectrum Ultraviolet juga pada spectrum Visible.

\section{REFERENSI}

Damayanti R, Mulyono, (2003), Khasiat \& manfaat daun sirih: obat mujarab dari masa ke masa,: Agromedia Pustaka, Jakarta.
McCabe, W.L, (1999), Operasi Teknik Kimia Jilid 1, Erlangga, Jakarta.

Peoloengan M, Chairul, Iyep K, \& Susan MN, (2006), Aktivitas antimikroba dan fitokimia dari beberapa tanaman obat, Seminar Nasional Teknologi, Balai Penelitian Veteriner, Bogor.

Putri ZF, (2010), Uji aktivitas antibakteri ekstrak etanol daun sirih (Piper betle L.) terhadap Propionibacterium acne dan Staphylococcus aureus multiresisten [skripsi], Universitas Muhammadiyah Surakarta, Surakarta.

Sudarsono, Pudjoarianto, A., Gunawan, D., Wahyuono, S., Donatus, I.A., Drajat, M., Wibowo, S., dan Ngatijan, (1996), Tumbuhan Obat, PPOT-UGM, Yogyakarta. 